investigation it would appear that chieftainship, kinship, and social organisation in general are intimately bound up with the economic organisation.

In the discussion which followed the reading of the paper all the speakers emphasised the value and originality of the view of primitive culture which Dr. Malinowski had formulated in his interesting communication. Prof. Seligman asked how far the elaborate organisation of garden cultivation depended upon the existence of the chieftainship. Among the Southern Massim of New Guinea, for instance, there were no chiefs, and the native social organisation was based upon the hamlet. Had the elaborate garden organisation been observed among such peoples?

Sir James Frazer agreed that the economic aspect of primitive culture had not been adequately studied. It was interesting to note how the tribal economics were saturated with magic, and how the fallacy of magic still persisted among people who had developed a high system of agriculture. The mention of torches used by the magician in the ceremonies led him to compare the torches to which reference was made in the Greek legends of Demeter's search for Persephone. Was it possible that these torches represented a survival of a use of torches in early Greek agricultural ceremonies similar to that to which they were put in the Trobriands?

Mrs. Routledge suggested that an analogous complexity of economic organisation might be found among the people of East Africa with whom $\mathrm{Mr}$. Routledge and herself had come into contact, where ivory played an important part.

Mr. Ray said that Dr. Malinowski had submitted a new view of ethnological investigation to the institute. Some of the ceremonies described by him suggested ceremonies from the other end of Melanesia, namelv. Lovaltv Island and New Caledonia, where the agricultural operations were directed by the chief, who prescribed what ground should be put under cultivation, the kind of crop, and the like, and received the first and best of the produce. Was it possible that these complex economic svstems existed wherever there were chiefs whose nosition, power, and prerogatives depended upon the fact that they were of extraneous origin?

The lecturer in his replv stated that although garden magic was carried out by the Southern Massim at Dobu. cultivation was not accompanied by such a complex organisation for distribution.

\section{The Organisation of Scientific Work in India.}

T HE Indian Industrial Commission during its tour through India found that all was not well with the scientific worker, especiaiily in connection with the application of his work to industrial development. While stating specifically in its report that "we do not propose to deal with the general problems of pure scientific research," it adds: "We were impressed by the value of the work which had already been done in the organised laboratories, and by the absolutely unanimous opinion which was expressed by all scientific officers as to the inadequacy of the staffs in point of numbers. Everywhere we were brought face to face with unsolved problems, requiring scientific investigation on an extended scale. On the one side, we saw the results accomplished by enthusiastic scientists, which, regarded from the purely economic aspect of the question, have added enormously to the productive capacity of India; on the other side, we were told by forest officers, agriculturists and indigo planters, engineers, and manufacturers, of the limitaNO. 2644 , VOL. IO5] tions placed upon the development of their work and the frequency with which they were brought to a standstill by a lack of knowledge regarding matters which could only be ascertained by systematic research work." It is clear from these and other passages that the Industrial Commission desired to direct attention to the necessity for the elaboration of some scheme by which an organised attack might be made on the large number of problems awaiting solution in connection with the development of industry, and the conclusion reached is that "the maintenance of a staff of suitable technologists and scientific experts is essential to industrial development.",

The Commission then gives its reasons for considering that it is the duty of the State to provide the necessary facilities, and concludes: "We have thus no hesitation in recommending a very substantial increase in the scientific and technical services as essential to industrial development." A general discussion follows as to the relative merits of a system in which the science is the bond, and one in which the bond is formed by the application of the sciences dealt with. In the first case the Geological Survey is given as an example, and the Agricultural and Forest Departments are quoted as examples of the second. But it is clear that the Commission was fully alive to the difference between a service and a deoartment. and realised that the differentiation given above was the same as that between a service and a department, because it savs: "The constitution of a certain number of scientific services based on the assumption that the science itself is a chief link between all members does not prevent the formation of departments. either Imperial or provincial, where the application of various sciences is the chief bond of union." The essential difference between the two types of organisation is clearly indicated in subjoined extracts from a despatch of the Government of India.

The Commission states that its proposals in the case of chemistry will have to be submitted to a special committee, and that it "hesitates to offer suggestions in greater detail regarding the organisation of the Imperial scientific servires for bacteriologv, botany, and zoology, as we consider that the best plan will be the appointment of special small committees for the purpose of formulating proposals." The first of these, that for chemistrv, has now reported, and the report is open for discussion. As regards other sriences, it would be best to await the reports of the other committees before offering any remarks upon them.

The following extracts from the Government of India's dispatch dated June 4, I9rg. place in a very clear light the intentions which underlie the recommendations of the Commission :-

\section{The Scientific Services.}

One of the main proposals refers to the constitution of scientific services and of an industrial service. The Commission direct attention to the extreme importance of research under modern industrial conditions, and to the especial needs of India, in view of her vast unexploited resources in raw material and of the paucity of her scientific workers. They criticise the complete lack of organisation among men of science employed by the Government, and describe the difficulties, both administrative and technical, to which this gives rise. The Commission recommend as a remedy the creation of a similar mechanism to that through which the Central and Local Governments have hitherto carried out almost all their most important activities, especially those requiring technical knowledge, viz. all-India services; and they discuss the basis on which these services should be con- 
stituted. The Commission propose the creation, not of scientific departments, but of scientific servicesan essential distinction which has been clearly brought out in the replies of Local Governments, though it has not been so clearly apprehended by critics of the proposal. The Commission contemplate the recruitment of officers into separate scientific services, such as a Chemical, Botanical, or Zoological Service, for employment under Imperial and provincial departments, such as Forests and Agriculture, which deal with the application of a number of separate sciences. They propose that scientific officers in the employ, of the Government, instead of being recruited in small numbers or single units into the different services which happen to require them, should be recruited as experts in their several sciences into scientific services, each with its appropriate conditions of qualification, pay, pension, and promotion. Although the services will be distinct entities for the above purposes, yet the only members of those services that will not be actually employed under the various departments that require their services will consist of a central staff, engaged under such officers, for instance, as Deputy Chief Chemists, at research centres, in scientific work. This central agency will also serve as a reservoir to meet the demands that may be put forward by other departments or by Local Governments for men to undertake temporary special investigations, to fill new posts or leave vacancies, or for the replacement of existing officers.

The head of each scientific service would thus exercise an influence over the members of his service in matters scientific, by the check of scientific results, and by the provision of advice and criticism on scientific work, whether for Local Governments or for research workers. It is not, we understand, proposed by the Commission, nor do we ourselves contemplate, that he should actually control research work in the sense of ordering definite problems to be taken up by officers serving under Local Governments, or should turn his department into a gang of hack researchers. We rely on constant correspondence between scientific officers of the same caste and periodical conferences as sufficient to correlate research programmes.

Local Governments and heads of Departments find the greatest difficulty in forming an opinion of the work done by men of science employed under them, or of the probable value of lines of research proposed by their officers. Should the administrative authority consider the results obtained by a man of science unsatisfactory, it is almost impossible to obtain an authoritative opinion on his work or qualifications; or to say whether he might not do better in another post; or to find such a post for him. The difficulties arising from the existence of isolated specialists in a department are, in fact, notorious.

The impossibility of applying any common measure in determining the respective claims to promotion of a botanist, a chemist, an engineer, and a political economist has been recognised in the existing services by the creation of separate posts on a time-scale. But this does not get over the difficulties already indicated, or supply the proper incentive to the research worker, or afford scope or prospects for men of more than average ability. The absence of such prospects is bound to militate against our chances of obtaining oood recruits, to render our staff discontented, and to prevent our securing the best work from the best men.

Moreover, so long as students of a particular science are recruited sporadically on behalf of different departments as vacancies occur, the Government will have to accept the men that happen to be left over. whatever their qualifications, after other and more NO. 2644, VOL. IO5] regular demands have been supplied. The prospect of regular annual recruitment will enable the Government of India to fill its future demands for men of science, as it has hitherto done for engineers, forest ofticers, and medical men.

The present system, under which the only chemists employed by the State are scattered through numerous departments without any organisation that can marshal the chemical forces of the country to attack problems of national importance, can give no help towards an active industrial policy.

We might quote as illustrating the inspiring value of a central co-ordinating authority, the work undertaken by the Munitions Board through its chemical adviser. The report of the conference of chemists at Lahore shows that even our isolated and scattered chemists can be moulded into one team for the purpose of suggesting new lines of research and means for turning the results to practical account without overlapping and consequent waste of effort.

This experience, in the light of the magnificent results obtained in England by the Research Committee of the Privy Council, shows clearly how much may be expected from a system which provides a permanent organic connection between all chemists in Government employ.

The importance of a common system of recruit ment and of a common service has recently been recognised by the council of the Institute of Chemistry in the United Kingdom (vide Proceedings of the Institute of Chemistry, I9I 8 , part iv., p. I4) in a representation submitted by them to all Government Departments in which chemists are employed. They state their opinion that "the time is opportune for taking steps to secure for the provision of chemistry a position corresponding to that occupied by the learned professions, and they feel that much would be accomplished towards the attainment of that end if, in the first place, adequate and uniform conditions of appointment were accorded to chemists directly engaged in the service of the State. The necessity for a definitely organised chemical service (both in peace and war) for all purposes of the State on which the science of chemistry has a bearing has long been recognised in the chemical profession."

Conditions in India render the services of chemists employed under Government of even greater relative importance than in England. India is far more deficient than England in the knowledge of its raw materials and of the appropriate industrial processes; consulting chemists and chemists in private employ are almost entirely absent here, and this deficiency is not likely soon to be remedied. Research institutes with special reference to a particular industry in England, it would seem, will usually be financed and controlled by the industry itself, with a Government grant-in-aid, whereas in India the position will be precisely the opposite, and the industry will relv primarily on State chemists. We therefore agree with the Commission that the advancement of industries in India must depend for scientific assistance almost entirely on State-employed men. and these men will be far more concerned with the initiation of important new lines of development and research and far less with mercly routine work than is the case in England. The need of organisation is the greater in that the functions of Indian State chemists are more important to the country; while their greater isolation and the consequent absence of a scientific atmosphere furnish an additional argument. The case for a State chemical service is thus even stronger in India than in England.

We are much influenced bv the prospects which the proposed system affords of increasing the number of 
Indians in the scientific services. An Indian appointed to an isolated post, or as an assistant to an isolated professor in a country where the scientific atmosphere is non-existent, or at the best exceedingly attenuated, lacks guidance and the stimulus of his fellows in the pursuit of scientific knowledge. His ambitions tend to become limited to the improvement of his pay and prospects rather than of his professional attainments. His membership of an all-India service, based on the pursuit of a common science, will increase the prestige of that science in his eyes and in those of the Indian public; the existence of the proposed Imperial nucleus of scientific workers under a distinguished chief will provide him with an incitement to excel with assistance in his studies and with opportunity for training if he desires it.

The Commission propose that, if the principle of scientific services is approved, committees should be appointed to formulate proposals for the permanent organisation and the terms of employment of each such service, and for the location and equipment of research laboratories. We support this recommendation, subject to the condition that the terms of reference to each committee should include a direction to report as to the advisability of constituting all-India services for each well-defined science.

Without anticipating the conclusions of the proposed committees, we think it desirable, in view of criticisms which have been expressed, to indicate certain principles in the general administration of these services which should govern the relations between the members of the scientific services and the heads of departments and provincial Governments, under whom many of them will be emploved.

We do not think that members of scientific services should be seconded by the method which the Commission propose, viz. by deputation for periods of five years at a time; but we consider that (as in the case of other services) an officer, when once placed permanently under the orders of a local Government. should remain with the Government for the rest of his service, unless the Government under which he is serving itself desires his transfer, or unless his services are required in a higher post or in a post requiring special qualifications outside the province, in which case the local Government will recognise that the Imperial Government has a claim on them. This is the system which exists at present in respect of all similar services.

Local Governments would have complete liberty to appoint, after consulting the head of the service, to any post in their industrial or scientific cadre, any available member of the respective services; they would also be at liberty, in the special circumstances arising during the initial stages, to appoint to such posts men outside the service; but the subsequent admission to the all-India service of men so appointed would be entirely controlled by the Secretary of State. The local Governments universally support the proposed scheme of scientific services, and though the Governments of the Punjab, the United Provinces, and Bombay, and the officers and public bodies consulted by them, put forward certain criticisms of the scheme, especially with reference to the position of men of science in the Education Department, these criticisms are, we think, fully met by the foregoing explanation of the lines on which we think the proposed services should be administered.

We desire, however, to add a few remarks with special reference to the case of science teachers. We fully recognise that much is required of a scientific professor in a college, outside his scientific work. $\mathrm{He}$ must look on himself as a member of the body responsible for the tone of the college and for its NO. 2644 , VOL. IO5] general success. It will, therefore, we agree, be most undesirable that such a man should continuously have in mind the possibility of promotion outside his own department. We think, however, that this difficulty will be obviated by the general principle laid down by us above, viz. that members of scientific services serving under the Department of Education should not be removed from that Department, unless at the request of the educational authorities, or for posts requiring high administrative capacity, or special scientific qualifications.

The advantage to the Education Department of a system of scientific services will still be very considerable. In the first place, we consider that, though university and college science workers should be by no means entirely divorced from technical research, their main sphere of activity should lie among problems of pure science. The proposed central scientific organisation should afford a means whereby such problems arising in the course of technical research can be referred to university and college laboratories.

Such co-ordination, both in respect of pure science problems and technical problems, can be most readily effected in cases where the educational researchers are themselves members of a scientific service. This policy will doubtless stimulate the interest in research work taken by students and professors. Officers who have entered the educational service as teachers may be in some cases expected to develop as research workers. The existence of all-India scientific services will afford a ready means for accommodating men whose aims in life have thus, been diverted from one form of work to another. In the next place, the present system of recruitment of men of science into the Educational Service is capable of improvement, and far better results could be obtained with the aid and advice of watchful central agencies in India. The absence of a scientific atmosphere, again, has been particularly injurious to scientific officers in the Educational Service, and has led to great stagnation in respect of research work. This atmosphere will in future reach individual officers by the numerous channels of communication which will be created between them and the central agency on technical subjects, whether by way of correspondence, conferences, and scientific publications, by the central staff's tours of inspection, or by officers spending some portion of their vacations at research institutes. The case of men of science at present employed under the Department of Education will obviously require careful treatment; such men should not be allowed to join the scientific services as a matter of course, but each case will have to be considered on its merits, and there may still be classes of appointments for which men will have to be recruited independently. Further, the whole question, so far as it affects the employment of officers with scientific qualifications in colleges and universities, will have to be reviewed in connection with the proposals of the Calcutta $\mathrm{Uni}$ versity Commission regarding recruitment.

In addition to the opinions expressed in the letters received from local Governments, two important conferences of chemists have recently put forward their views on the Commission's proposals. A record of their discussions is appended. A full meeting of the Sectional Conferene of Agricultural Chemists at Pusa in February passed the following resolution :-

"That this Conference considers that, in view of the intense local knowledge required for effective work for agricultural improvement by chemical methods, it is not desirable that the chemists in the Agricultural Departments should be formed into a service apart from the ordinary agricultural service, 
in which the bond of union would be the science rather than its application. On the other hand, in addition to agricultural chemists attached to the Provincial Departments, this Conference is definitely of opinion that a strong central body of chemists should be maintained by the Imperial Department of Agriculture from whom Provincial Departments could draw for the investigation of special problems."

The main objection taken was, it will be observed, based on the idea that men would usually be transferred after five-year periods. We have explained already that such idea forms no part of the system which we contemplate. It is also significant that the same resolution declared the necessity of a strong central body of chemists for the Department of Agriculture; and, it may be added, the same meeting pointed out the desirability of equipping the agricultural research organisation to deal with certain industrial problems arising out of agricultural research. The sum of these conclusions seems to point to the desirability of supplying some agency which can correlate chemical research with agricultural and industrial problems, and of avoiding the needless expense of creating separate research nuclei for dealing with each separate class of chemical problems.

A conference of chemists was convened in Lahore in January, rgis, by the Indian Munitions Board. It included not only Government officers, but also chemists attached to missionary colleges and emploved under private firms. The conference passed no formal resolution, but strongly supported the proposed svstem of scientific services.

\section{University and Educational Intelligence.}

CAMBridge.--As stated in our issue of June 24 (p. 537), a donation of roool. has been received for the provision of lectures on tropical agriculture for five years. Dr. C. A. Barber has been appointed as lecturer in tropical agriculture.

Dr. F. W. Aston has been elected to a fellowship in Trinity College.

In presenting Sir Joseph Thomson and Sir Joseph Larmor for honorary degrees at Cambridge recently, the Public Orator spoke as follows: "Democritus, philosophus ille antiquus, ut mundum explicaret, atomos finxit, solida rerum primordia, non partium conventu conciliata,

'sed magis æeterna pollentia simplicitate.'

Sed, ut discipulus illius ait, difficile est credere in rebus esse quidquam solido corpore, quod demonstravit Professor noster. Atomum enim ipsum ingressus, partes discrevit, ordinavit, legibus subjecit. Immo ut Græcus ex atomo кó $\mu_{0 \nu}$ eduxit, Anglus in atomum $\kappa o ́ \sigma \mu o \nu$ introduxit. Et multa quidem ejusmodi investigavit, quæ dicere non concedit Latini sermonis egestas; hoc saltem concedit exponere, quanta universorum lætitia collegio suo Magistrum a Rege impositum nuper viderimus." And: "Adest alter e burgensibus nostris, idem rei physicæ Professor, Isaaci Newton et Greorgii Gabrielis Stokes non indignus successor, Societatis Regiæ olim a secretis, qui scientias innumeras provinciam sibi depoposcit et illustravit. Ut carmen quoddam cenaticun discipulorum commemoremus

' æthera materiemque electraque cogitat ille

somnia quæ possint mentes confringere nostras.'

Sed quem mundus ut virum sollertem ingeniosum sapientem miratur, illum collegium suum amicum diligit, providum modestum fidelem. Quem si amplissimis honoribus hodie extollit Academia nostra, hoc multæ et apud nos et apud exteros facere occupaverunt."

NO. 2644 , VOL. IO5]
EDINBURGH.-Her Majesty the Queen has consented to accept the honorary degree of LL.D. on the occasion of the impending laying of the foundation-stone of the new chemistry department.

GLASGOW.-The degree of D.Sc. was conferred on June 23 on the following:-P. A. Hillhouse, for his thesis "Ship Stability and Trim," with other papers, and D. B. Meek, for his thesis "Cyclonic Storms' in the Bay of Bengal for a period of thirty years, from I886 to I9I5 inclusive, with special reference to their Location and Direction of Motion," with other papers.

On the same occasion the following special class prizes were awarded : - Mathematics (Advanced Honours Class): The Cunninghame gold medal to J. M'Kinnell. Natural Philosophy (Ordinary Class) : The Cleland gold medal to D. H. Findlay. Political Economy: The Alexander Smart memorial prize to Stewart Mechie. Moral Philosophy (Honours Class): The Edward Caird medal to I. W. Phillips.

On June 24 the degree of LL.D. was conferred on Dr. J. MacIntyre and Sir Robert W. Philip.

London.-At a meeting of the Senate on June 23 Dr. S. Russell Wells was re-elected Vice-Chancellor for the year $1920-21$.

Communications were received from the University College Committee and from the Dean of the University College Hospital Medical School, setting forth respectively the terms of the recently published offers made by the Rockefeller Foundation to present $(a)$ to the University, on behalf of University College, the sum of $370,000 l$. , and $(b)$ to University College Hos. pital Medical School the sum of $835,000 l$, for the advancement of medical education and research. Resolutions were adopted expressing the Senate's grateful appreciation of the magnificent generosity shown by the Trustees of the Foundation to the University and to the Medical School of University College Hospital, and accepting the offer made for the benefit of University College.

Mr. A. E. Jolliffe, tutor in mathematics at Corpus Christi College, Oxford, was appointed to the University chair of mathematics tenable at the Royal Holloway College; Dr. B. J. Collingwood (professor of physiology at University College, Dublin) to the University chair of physiology tenable at St. Mary's Hospital Medical School; Prof. L. R. Dicksee to the Sir Ernest Cassel chair of accountancy and business methods tenable at the London School of Economics and Political Science; Mr. H. C. Gutteridge to the Sir Ernest Cassel chair of commercial and industrial law tenable at the London School of Economics and Political Science; Mr. T. E. G. Gregory to the Sir Ernest Cassel readership in commerce, with special reference to foreign trade, tenable at the London School of Economics and Political Science; Mr. D. Knoop to the Sir Ernest Cassel readership in commerce, with special reference to the organisation of industry and trade in the United Kingdom, tenable at the London School of Economics and Political Science; Mr. H. Dalton to the Sir Ernest Cassel readership in commerce, with special reference to tariffs and taxation, tenable at the London School of Economics and Political Science; Mr. L1. Rodwell Jones to the University lectureship in commerce, with special reference to commercial geography, tenable at the London School of Economics and Political Science; Mr. J. D. Smith to the University lectureship in commerce with special reference to business organisation. tenable at the London School of Economics and Political Science; and Mr. T. A. Joynt to the University lectureship in commerce, with special reference to transport and shipping, tenable at the London School of Economics and Political Science.

Grants from the Dixon Fund for 1920-2I were 